\title{
Molecular classification of selective oestrogen receptor modulators on the basis of gene expression profiles of breast cancer cells expressing oestrogen receptor $\alpha$
}

\author{
AS Levenson*,', IL Kliakhandler², KM Svoboda', KM Pease', SA Kaiser', JE Ward III' and VC Jordan' \\ 'Robert H Lurie Comprehensive Cancer Center, Northwestern University Medical School, 303 E. Chicago Avenue, Chicago, Illinois, IL 606 II, USA; ${ }^{2}$ Department \\ of Mathematical Science, Michigan Technology University, Houghton, Michigan, MI 49931-1295, USA
}

The purpose of this study was to classify selective oestrogen receptor modulators based on gene expression profiles produced in breast cancer cells expressing either wtER $\alpha$ or mutant ${ }_{35}$ IER $\alpha$. In total, 54 microarray experiments were carried out by using a commercially available Atlas cDNA Expression Arrays (Clontech), containing 588 cancer-related genes. Nine sets of data were generated for each cell line following $24 \mathrm{~h}$ of treatment: expression data were obtained for cells treated with vehicle $\mathrm{EtOH}$ (Control); with $10^{-9}$ or $10^{-8} \mathrm{M}$ oestradiol; with $10^{-6} \mathrm{M}$ 4-hydroxytamoxifen; with $10^{-6} \mathrm{M}$ raloxifene; with $10^{-6} \mathrm{M}$ idoxifene, with $10^{-6} \mathrm{M} \mathrm{EM} \mathrm{652,} \mathrm{with} 10^{-6} \mathrm{M}$ GW 7604; with $5 \times 10^{-5} \mathrm{M}$ resveratrol and with $10^{-6} \mathrm{M} \mathrm{ICl}$ 182,780. We developed a new algorithm 'Expression Signatures' to classify compounds on the basis of differential gene expression profiles. We created dendrograms for each cell line, in which branches represent relationships between compounds. Additionally, clustering analysis was performed using different subsets of genes to assess the robustness of the analysis. In general, only small differences between gene expression profiles treated with compounds were observed with correlation coefficients ranged from 0.83 to 0.98 . This observation may be explained by the use of the same cell context for treatments with compounds that essentially belong to the same class of drugs with oestrogen receptors related mechanisms. The most surprising observation was that $\mathrm{ICl}$ 182,780 clustered together with oestrodiol and raloxifene for cells expressing wtER $\alpha$ and clustered together with EM 652 for cells expressing mutant ${ }_{35} \mathrm{ER} \alpha$. These data provide a rationale for a more precise and elaborate study in which custom made oligonucleotide arrays can be used with comprehensive sets of genes known to have consensus and putative oestrogen response elements in their promoter regions. British Journal of Cancer (2002) 87, 449-456. doi: 10.1038/sj.bjc.6600477 www.bjcancer.com

(c) 2002 Cancer Research UK

Keywords: SERMs; ER $\alpha$; gene expression profiles; breast cancer cells

Selective oestrogen receptor (ER) modulators (SERMs) are a new class of drugs, which have a profound impact in breast cancer treatment and prevention (Levenson and Jordan, 1999). Tamoxifen is one of the most effective SERM for the treatment of ER positive breast cancers; however, despite the initial favourable response to tamoxifen therapy, eventually tumours become refractory to treatment resulting in disease recurrence (Tonetti and Jordan, 1995). Often these tumours will subsequently respond to alternative hormonal therapy.

It is well known that there are mechanistic differences among SERMs because following binding to ER each ligand induces a distinct ER-ligand conformation, that is recognised distinctly by the transcription machinery (Wijayaratne et al, 1999). It is, therefore, logical to assume that individual SERMs induce different gene expression profiles. Identification of additional SERMs, on the basis of their differential gene expression profiles, could be useful in predicting outcome of the second-line therapy.

Differential pharmacology of SERMs is best represented in different tissues. Table 1 summarises the in vivo pharmacological

*Correspondence: AS Levenson; E-mail: a-levenson@northwestern.edu Received 7 December 200 I; revised 27 February 2002; accepted 27 May 2002 and/or therapeutic activities of compounds used in this study. The mechanisms of oestrogen action by binding two specific intracellular ERs $(\alpha$ and $\beta$ ) reviewed in (Nilsson et al, 2001). The antioestrogen tamoxifen has oestrogenic activities in the bone, uterus and the cardiovascular system (Bagdade et al, 1990; Ryan et al, 1991; Love et al, 1994; Barrett-Connor et al, 1999) and is an anti-oestrogenic in the breast (Jordan, 2000; Morrow and Jordan, 2000). Raloxifene (Ral), on the other hand, has less oestrogenic effects on uterus, but the same beneficial effects on bone and lipid metabolism (Delmas et al, 1997; Barrett-Connor et al, 1999; Cohen et al, 2000) while it is an antagonist of oestrogen action in the breast (Gottardis and Jordan, 1987; Cummings et al, 1999). Other SERMs like idoxifene (Idox) (Chander et al, 1991; Nuttall et al, 1998), GW 5638 (Willson et al, 1994, 1997; Connor et al, 2001) and EM 800 (Luo et al, 1998; Labrie et al, 1999; Martel et al, 2000) are different from tamoxifen and based on their activity in the rodent uterus are more closely related to raloxifene. Resveratrol (Res) does not formally belong to the SERM family, because it is a phytoestrogen found in the plants (Jang et al, 1997), however Res has similar in vivo characteristics to the SERMs (Mizutani et al, 2000; Bhat and Pezzuto, 2001; Wu et al, 2001). ICI 182,780 (ICI) is a pure anti-oestrogen with anti-oestrogenic activities in almost all tissues, with no changes in serum lipids and on bone density (Wakeling and Bowler, 1987; Wakeling et al, 1991; Lee et 
Table I Summary of oestrogen-like and anti-oestrogen-like activities of SERMs used in this study

\begin{tabular}{|c|c|c|c|c|}
\hline Compound & Structure & $\begin{array}{c}\text { Oestrogen-like } \\
\text { effects }^{\mathrm{a}}\end{array}$ & $\begin{array}{c}\text { Anti-oestrogen-like } \\
\text { effects }\end{array}$ & References \\
\hline Oestradiol & & $\begin{array}{c}\text { Breast } \\
\text { Uterus } \\
\text { Bone } \\
\text { Lipid metabolism }\end{array}$ & - & Nilsson et al (2001) \\
\hline Tamoxifen $^{b}$ & & $\begin{array}{c}\text { Uterus } \\
\text { Bone } \\
\text { Lipid metabolism }\end{array}$ & Breast & $\begin{array}{l}\text { Bagdade et al (1990); } \\
\text { Barrett-Connor et al } \\
\text { (1999); Love et al } \\
\text { (1994), Ryan et al (1991) } \\
\text { Morrow and Jordan (2000) }\end{array}$ \\
\hline Raloxifene & & $\begin{array}{c}\text { Bone } \\
\text { Lipid metabolism }\end{array}$ & $\begin{array}{l}\text { Breast } \\
\text { Uterus }\end{array}$ & $\begin{array}{c}\text { Barrett-Connor et al } \\
\text { (1999); Cohen et al } \\
\text { (2000); Delmas et al } \\
\text { (1997); } \\
\text { Gottardise and Jordan } \\
\text { (1987) }\end{array}$ \\
\hline Idoxifene & & $\begin{array}{c}\text { Bone } \\
\text { Lipid metabolism }\end{array}$ & $\begin{array}{l}\text { Breast } \\
\text { Uterus }\end{array}$ & $\begin{array}{l}\text { Chander et al (1991); } \\
\text { Nuttall et al (1998) }\end{array}$ \\
\hline GW $5638^{\mathrm{b}}$ & & $\begin{array}{c}\text { Bone } \\
\text { Lipid metabolism }\end{array}$ & $\begin{array}{l}\text { Breast } \\
\text { Uterus }\end{array}$ & $\begin{array}{c}\text { Connor et al (2001); } \\
\text { Willson et al (1994), (1997) }\end{array}$ \\
\hline EM $800^{b}$ & & $\begin{array}{c}\text { Bone } \\
\text { Lipid metabolism }\end{array}$ & $\begin{array}{l}\text { Breast } \\
\text { Uterus }\end{array}$ & $\begin{array}{l}\text { Labrie et al (1999); Luo } \\
\text { et al (1998); Martel et } \\
\text { al (2000) }\end{array}$ \\
\hline Resveratrol & & $\begin{array}{c}\text { Bone } \\
\text { Lipid metabolism }\end{array}$ & $\begin{array}{l}\text { Breast } \\
\text { Uterus }\end{array}$ & $\begin{array}{c}\text { Jang et al (1997); } \\
\text { Bhat and Pezzuto (2001); } \\
\text { Mizutani et al (2000) } \\
\text { Wu et al (2001) }\end{array}$ \\
\hline $\mathrm{ICl} 182,780$ & & - & $\begin{array}{l}\text { Breast } \\
\text { Uterus }\end{array}$ & $\begin{array}{c}\text { Lee at al (2000); } \\
\text { Wakeling and Bowler } \\
\text { (1987); Wakeling et al } \\
\text { (1991); Howell et al } \\
(2000)\end{array}$ \\
\hline
\end{tabular}

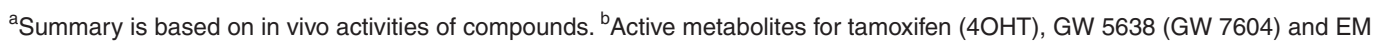
(EM652) were used in this study.

al, 2000). ICI 182,780 is currently in Phase III clinical trials for the treatment of advanced breast carcinoma (Howell et al, 2000).

Although it is possible to determine quantitatively the expression of thousands of genes in a single sample, there are significant technical issues to address for a comparison of gene expression profiles induced by a SERM-ER complex in different tissues. Cellular heterogeneity of different tissues is one of the problems. An approach to this issue would be to use a system in vitro to characterise different compounds and their differential pharmacology. We have developed a model system in vitro, in which some SERMs demonstrate oestrogen-like activities while others remain antioestrogenic (Levenson et al, 1997, 1998a,b,c, 2001; Levenson and Jordan, 1998).

The goal of this study was to classify SERMs on the basis of gene expression profiles of breast cancer cells expressing either wtER $\alpha$ (D351) or mutant ${ }_{351} E R \alpha$ (D351Y) after exposure to SERMs for $24 \mathrm{~h}$. To our knowledge this is the first attempt to classify SERMs using cDNA microarrays. We chose a well characterised model system in vitro in which cellular machinery is adapted for ERnonmediated transcription of genes (MDA-MB-231 cells), and 
oestrogen-responsiveness is restored by introduction of the ER gene into cells. The D351Y mutation in ER, changes SERM-induced transcriptional activities of endogenous gene expression (Levenson et al, 1997, 1998b,c, 2001; Levenson and Jordan, 1998; MacGregor Schafer et al, 1999) in these cells.

Different analytical tools have been proposed for analysing microarray data (Eisen et al, 1998; Golub et al, 1999; Kalocsai and Shams, 2001; Tamayo et al, 1999; Toronen et al, 1999; Bittner et al, 2000). Our goal was to identify the gene expression profiles of cells treated with the drug, compare the profiles from all samples (cells treated with different drugs) and then cluster similar from different profiles. We describe a new algorithm 'Expression Signatures' for the classification of compounds based on differential gene expression profiles of cells treated with these compounds.

\section{MATERIALS AND METHODS}

\section{Tissue culture}

The cells stably expressing wtER $\alpha$ and mutant ${ }_{351} E R \alpha$ used in this study were constructed from the ER-negative MDA-MB-231 human breast cancer cells as described previously (Jiang and Jordan, 1992; Catherino et al, 1995). The level of ER $\alpha$ in both cell lines is comparable to the level of ER $\alpha$ in MCF-7 cells. Cells were maintained in phenol red-free MEM with 5\% charcoal-dextran treated calf serum, supplemented with $100 \mu \mathrm{g} \mathrm{ml}^{-1}$ streptomycin, 100 units $\mathrm{ml}^{-1}$ penicillin, $2 \mathrm{mM} \mathrm{L}$-glutamine, $6 \mathrm{ng} \mathrm{ml}^{-1}$ bovine insulin, $100 \mathrm{~mm}$ nonessential amino acids, and $500 \mu \mathrm{g} \mathrm{ml}^{-1} \mathrm{G} 418$. All of the tissue culture solutions were from Life Technologies, Inc. (Gaithersburg, MD, USA).

\section{Hormones}

$17-\beta$ Oestradiol (E2) and Res were purchased from Sigma Chemical Co. (St. Louis, MO, USA). 4-OHT, EM-652 and ICI 182,780 were gifts from Dr Alan Wakeling (ICI Pharmaceuticals Macclesfield, UK). Raloxifene was a generous gift from Eli Lilly Research Laboratories (Indianapolis, IN, USA). GW 7604 was a generous gift from Dr Timothy Willson (Glaxo Wellcome Inc., Durham, NC, USA). Idoxifene was a gift from Smith Kline Beecham (Philadelphia, PA, USA). All compounds used in the experiments were dissolved in $100 \%$ ethanol and added to the medium in $1: 1000$ dilutions for a final ethanol concentration no higher than $0.2 \%$.

\section{cDNA array-based expression profiling}

We used AtlasTM Human cDNA Expression Arrays (Clontech, Palo Alto, CA, USA), containing cDNA fragments representing 588 known cancer-related genes and nine housekeeping genes. A complete list of the 588 genes of the AtlasTM Human Expression Array used can be accessed through the Internet at http:// www.clontech.com.

Total RNA was isolated using TRIZOL reagent (Gibco-BRL) as described previously (Levenson et al, 1997). The preparation and hybridisation of ${ }^{32} \mathrm{P}$-labelled cDNA from $5 \mu \mathrm{g}$ of total RNA were performed as described in the manufacturer's protocol. The experiments for each condition were conducted three times with at least two sets of RNAs and two different membranes. The hybridised membranes were exposed for $72-96 \mathrm{~h}$ at $-80^{\circ} \mathrm{C}$ using BioMax TranScreen HE Intensifying Screen (Kodak, Rochester, NY, USA). Signal intensities at each cDNA spot were detected by phosphorimage analysis using a Molecular Dynamic Storm phosphoimager (Molecular Dynamics, Sunnyvale, CA, USA). Initial analysis was performed using AtlasImageTM 1.5 software (Clontech). Following background correction, each gene on the membrane was normalised to a reference GAPDH then the signal intensity was calculated for each spot on the array and reported in an Excel database. For further analysis of the data (see below) 'all to one' normalisation was applied when all samples (treated with compounds) were normalised to one sample (untreated control).

\section{'Expression signatures' analysis}

A new method for classification of different compounds on the basis of gene expression profiles entitled 'expression signatures' was developed by our group. The method involved the following steps. Genes were reordered in the ascending order of their expression levels in the untreated samples. We denoted the expression of a gene with number ' $i$ ' in reordered set as $E_{i}$, where sub-index ' $i$ ' corresponds to the gene number, and $\mathrm{E}_{\mathrm{i}}$ means an expression level of that gene. Therefore, $E_{j}>E_{i}$ for $j>i$. Further, the data in gene arrays obtained under the influence of compound $\mathrm{R}$ were arranged in the same order, and were denoted as $E_{i}^{(R)}$. We propose the following formula to compute rescaled gene expressions $\mathrm{P}_{\mathrm{i}}$ :

$$
\mathrm{P}_{\mathrm{i}}=\log _{2}\left(\mathrm{E}_{\mathrm{i}} / \mathrm{E}_{\text {norm }}+1\right)
$$

$\mathrm{E}_{\text {norm }}$ is normalizing coefficient. In the present work, we adopted the following expression for $E_{\text {norm }}$ : $E_{\text {norm }}=E_{\text {ref }} / E_{\min }{ }_{1 / 2}$. We used GAPDH as a reference $\left(\mathrm{E}_{\mathrm{ref}}\right)$, and $\mathrm{E}_{\mathrm{min}}$ is the minimal level of intensity identified in the experiments. If sets of $\mathrm{E}_{\mathrm{i}}$ correspond to the untreated sample, we get sets of $\mathrm{P}_{\mathrm{i}}{ }^{(0)}$ of scaled gene profiles; for samples treated with compound $R$, we obtain $P_{i}{ }^{(R)}$. The formula (1) has two important properties: (a) original expressions $\mathrm{E}_{\mathrm{i}}=0$ are transformed into rescaled $\mathrm{P}_{\mathrm{i}}=0$, and (b) for high $\mathrm{E}_{\mathrm{i}}$ the formula is asymptotically logarithmic with base 2 . Next, we plot $P_{i}^{(R)}$ for each compound versus $\mathrm{P}_{i}^{(0)}$ of untreated sample. This is called the 'expression signature' of the compound. Similarities or differences between gene expression profiles produced by compounds $\mathrm{R}$ and $\mathrm{Q}$ can be calculated using Euclidian distance $\mathrm{D}[\mathrm{R}, \mathrm{Q}]$ :

$$
* \mathrm{D}[\mathrm{R}, \mathrm{Q}]=\left[(1 / \mathrm{n}) \Sigma_{\mathrm{i}}\left(\mathrm{R}_{\mathrm{i}} \quad \mathrm{Q}_{\mathrm{i}}\right)^{2}\right]^{1 / 2}
$$

where $\mathrm{n}$ is total number of genes. Interpretation of the distances and signatures allows grouping of the compounds on the basis of gene expression profiles produced.

The intrinsic gene list that formed the basis for the classification was selected for each cell line to include those which showed good reproducible expression data from each of the three experiments performed for each compound and those which had intensity higher than 4000. This subset of genes for cells expressing wtER $\alpha$ was represented by 87 genes and for those expressing mutant ${ }_{351} \mathrm{ER} \alpha$ by 117 genes. (Complete data sets for expression profiles are available at http://www.math.mtu.edu/ igor/Gene_index.html.)

\section{Cluster analysis}

We extracted normalised expression data for cells expressing wtER $\alpha$ from an Excel data base generated by AtlasImage ${ }^{\mathrm{TM}} 1.5$ software (Clontech). The same criteria of reproducibility and accuracy were applied to select subsets of genes from the 588 cDNAs on the array. Clustering was performed using the subset of up-regulated genes after treatment with compounds compared to the control untreated cells.

We applied a hierarchical clustering algorithm described by Eisen et al (1998) and available as 'Cluster and TreeView' manual at http://rana.stanford.edu/software. The results of this process were two dendrograms, one for the compounds and one for the genes. The dendrogram for the compounds is of interest for the current study.

\section{RESULTS}

We identified gene expression profiles in MDA-MB-231 human breast cancer cells transfected with either wtER $\alpha$ or mutant ${ }_{351} \mathrm{ER} \alpha$ following treatment with E2, SERMs (4OHT, Ral, Idox, GW, EM, 
A
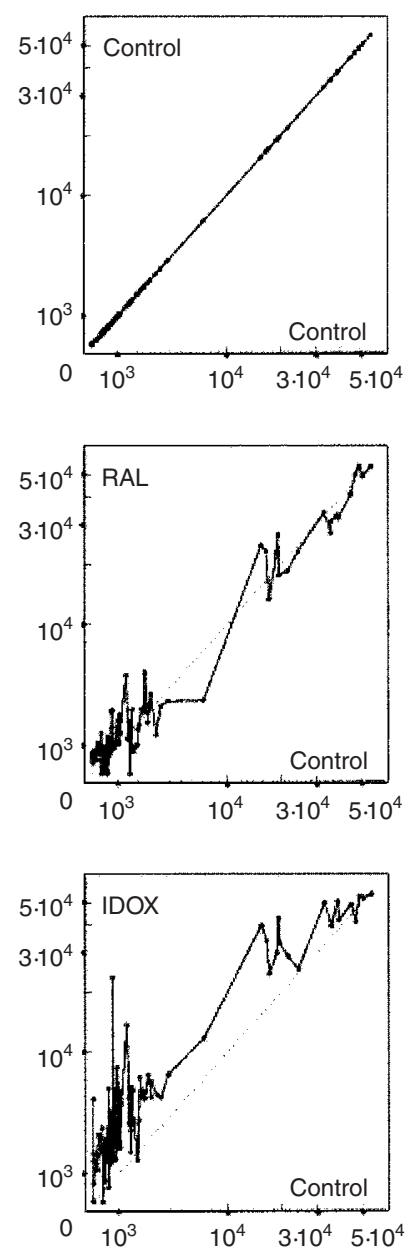
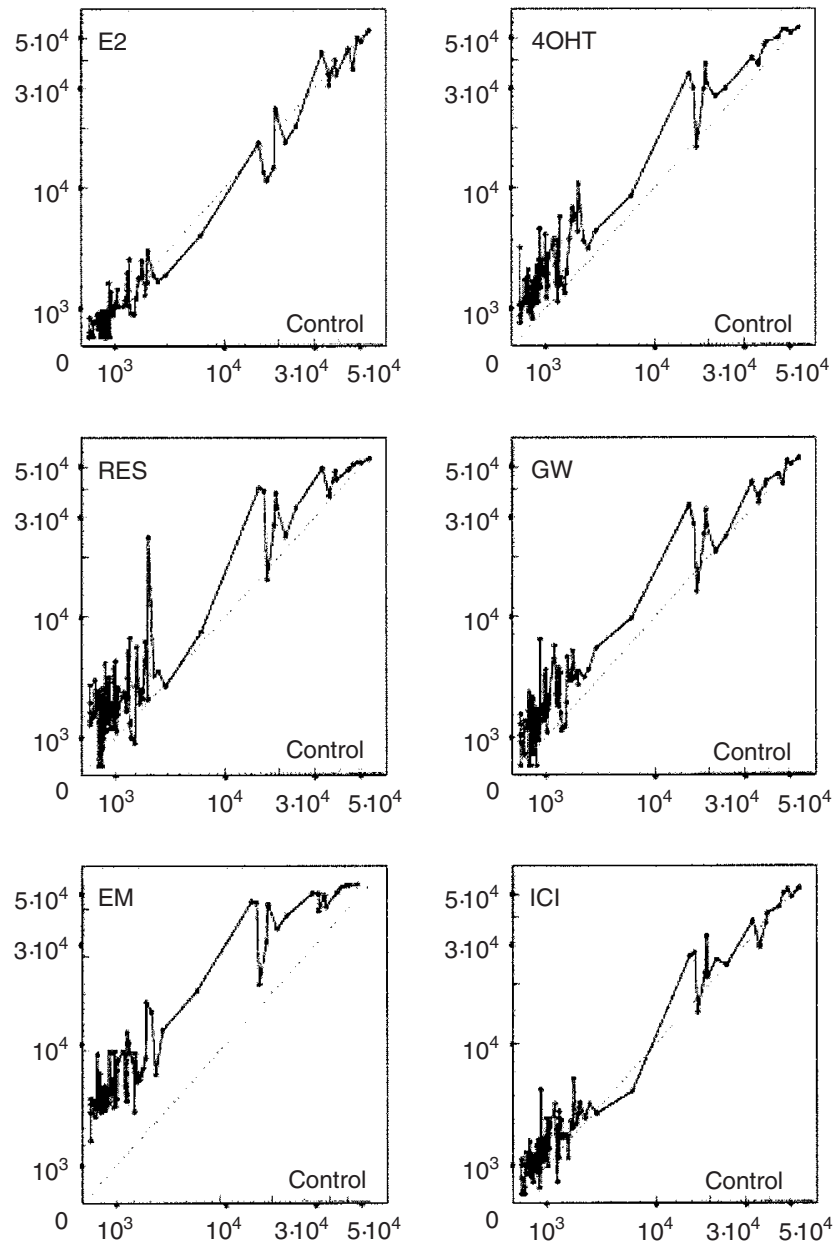

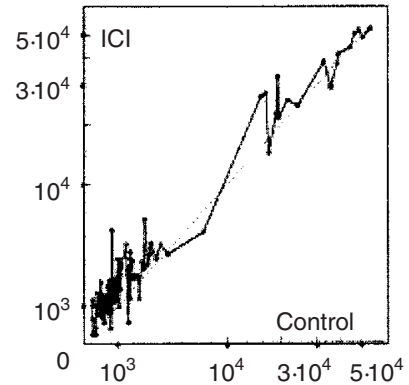

B

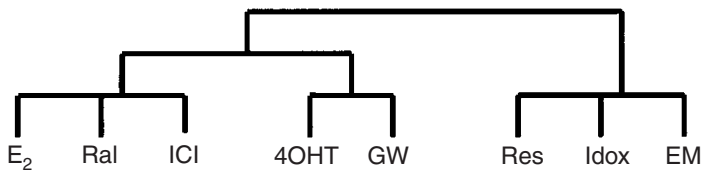

Figure I Expression signatures of cells treated with different compounds (E2, SERMs and ICI) versus the untreated control cells are shown. Eighty-seven selected genes were used to create 'Signatures' for cells expressing wtER $\alpha(\mathbf{A})$ and dendrogram representing similarities in the expression patterns of cells treated with different compounds were created from 'expression signatures' on the basis of data from distance metric and correlation coefficients (B). The branching patterns in the resulting dendrogram organised the compounds into three main groups: E2: Ral:ICl; 4OHT: GW; and Res: Idox: EM. Normalised values for selected subset of genes were used for all manipulations. The values of normalised adjusted intensities representing levels of expressions of the vehicle-treated control (X-axis) and the compound-treated (Y-axis) cells are shown for $\mathbf{A}$.

Res) and pure anti-oestrogen ICI. In total, 54 microarray experiments were carried out. Nine sets of data were generated for each cell line following $24 \mathrm{~h}$ of treatment: gene expression profile for cells treated with vehicle EtOH (Control); with $10^{-9}$ or $10^{-8} \mathrm{M} \mathrm{E2}$; with $10^{-6} \mathrm{M} 4 \mathrm{OHT}$; with $10^{-6} \mathrm{M}$ Ral; with $10^{-6} \mathrm{M}$ Idox, with $10^{-6} \mathrm{M}$ $\mathrm{EM}$, with $10^{-6} \mathrm{M} \mathrm{GW}$; with $5 \times 10^{-5} \mathrm{M}$ Res and with $10^{-6} \mathrm{M}$ ICI. The concentrations of compounds for each cell line used in this study have been determined previously (Levenson et al, 1997; 1998a,b,c, 2001) and the maximally effective dose for each compound was chosen for the array experiments.

We developed a new algorithm 'expression signatures' (see Materials and Methods) to classify compounds based on differen- tial gene expression modulation. In contrast to the hierarchical cluster analysis this method allows the use of raw normalised data sets without any major modification of the data. We first considered the whole set of 588 genes represented on the array to compare the 'signatures' of compound-treated cells. However, based on our findings of unacceptable experimental variations and artefacts produced by the microarray technology itself, we searched for genes that were not influenced by the experimental variations (see Materials and Methods). Figure 1A shows 'expression signatures' of cells expressing wtER $\alpha$ treated with different compounds for $24 \mathrm{~h}$. Interpretation of the signatures on basis of calculated 'distances' between the compounds showed similarities 
A
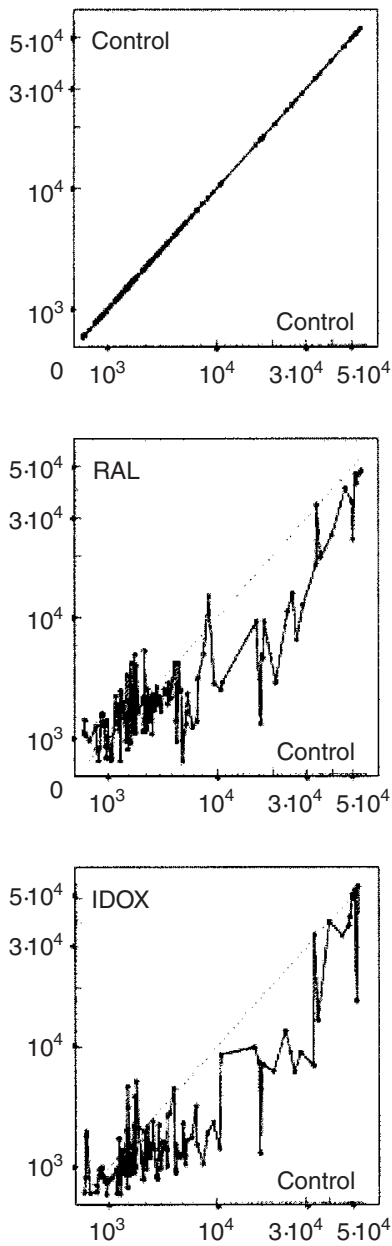
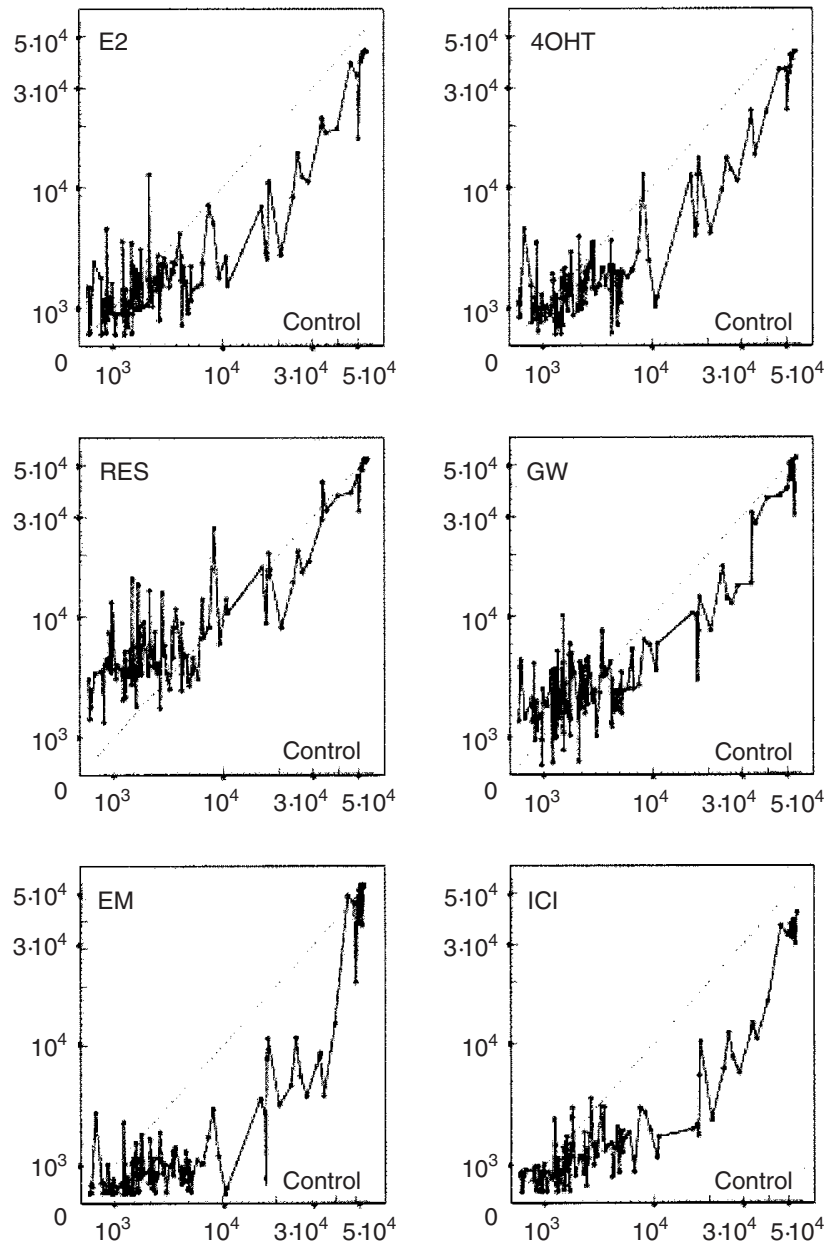

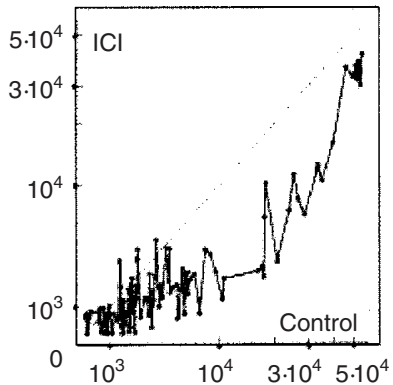

B

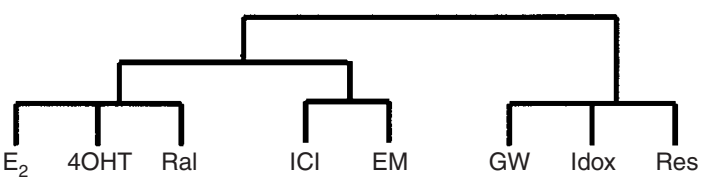

Figure 2 Expression signatures of cells treated with different compounds (E2, SERMs and ICI) versus the untreated control cells are shown. One hundred and 17 selected genes were used to create 'Signatures' for cells expressing mutant ${ }_{35}$ I ER $\alpha(D 35 \mid Y)(\mathbf{A})$ and dendrogram representing similarities in the expression patterns of cells treated with different compounds were created from 'expression signatures' on the basis of data from distance metric and correlation coefficients (B). The branching patterns in the resulting dendrogram organised the compounds into three main groups: E2: 4OHT: Ral; ICl: EM; and GW: Idox: Res. Normalised values for selected subset of genes were used for all manipulations. The values of normalised adjusted intensities representing levels of expressions of the vehicle-treated control (X-axis) and the compound-treated (Y-axis) cells are shown for $\mathbf{A}$

and differences between expression profiles of studied compounds. The resulting dendrogram for wtER $\alpha$ (Figure 1B) produced with a selected subset of genes (87 genes) (see Materials and Methods), resembled closely the dendrogram with all 588 genes (data not shown). Surprisingly, E2, Ral and ICI grouped together, the next closest is the group containing $4 \mathrm{OHT}$ and GW, whereas Res, Idox and EM were on the most distant dendrogram branches. This means that EM had lower correlation to the Control untreated cells, whereas E2 had the highest correlation to the untreated cells. When 117 selected groups of genes were used for 'expression signatures' of cells expressing mutant ${ }_{351} \mathrm{ER} \alpha$, the resulting dendrogram (Figure 2A,B) showed slightly different branching patterns. This time the most distant branches from the E2, 4OHT and Ral group was the GW, Idox and Res group.
The hierarchical clustering (Eisen et al, 1998) is often used as a multivariate technique to find groups of genes with similar expression profiles across a number of experiments and to group the experimental samples according to the similarities in their overall patterns of gene expression. This method was successfully applied for tumour, tissue or cancer cell line classification purposes (Ben-Dor et al, 2000; Perou et al, 2000; Ross et al, 2000; Gruvberger et al, 2001; Sorlie et al, 2001; Welsh et al, 2001). To examine the robustness of the observed clustering patterns by 'Expression signatures', hierarchical cluster analysis (see Materials and Methods) was performed by using subsets of up-regulated genes for each of seven experimental conditions for cells expressing wtER $\alpha$ (Figure 3). Once again, E2, Ral and ICI clustered together while cells trea- 


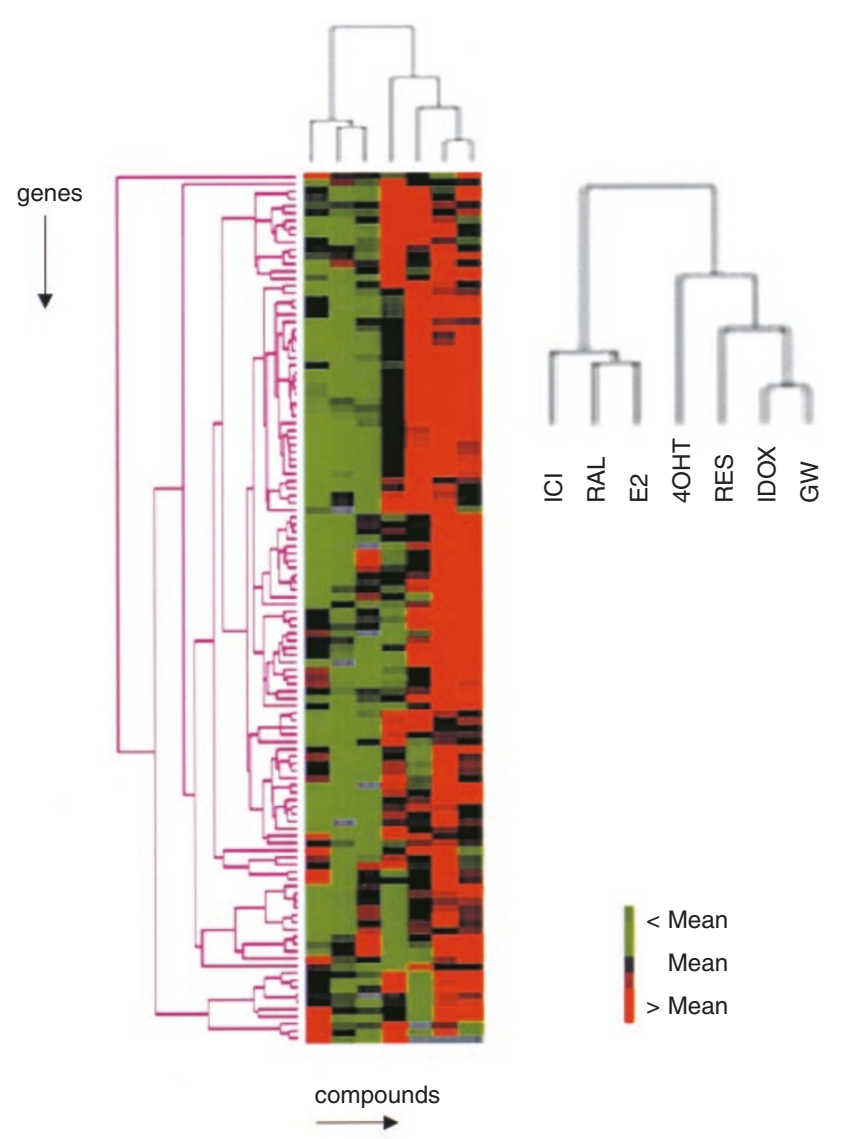

Figure 3 Gene expression patterns of cells expressing wtER related to treatment with compounds (E2, SERMs and ICl). Two-dimensional hierarchical clustering was applied to up-regulated subset of expression data from a total of 588 cDNAs measured across seven different treatments. A cluster dendrogram representing the hierarchical relationships between gene expression profiles of cells (vertically) and compounds (horizontally) was then generated. Colour-coded gene expression values for genes are shown. The colour reflects the mean-adjusted expression level of the gene: black is the mean, red is greater than the mean and green is less than the mean.

ted with 4OHT, Res, Idox and GW formed another big branch of the dendrogram.

Therefore, this data suggests that the classification of SERMs is relatively robust with $\mathrm{E} 2$, Ral and ICI staying together in the same cluster when using different sets of selected genes for analysis.

\section{DISCUSSION}

The biological effects of oestrogen and SERMs in breast cancer are mediated by the ER, a transcriptional regulator that controls the pattern of gene expression. The crystal structures of the ligand binding domain (LBD) of wtER $\alpha$ with agonists (E2 and DES) and antagonists (Ral and 4OHT) (Brzozowski et al, 1997; Shiau et al, 1998) confirmed the central role of the ligand in modulating ER conformation. It is now clear that each ligand upon binding, induces unique structural alterations within the ER, changing its conformation and its transcriptional activity. This means that subsequent gene expression results from the ER-SERM complex activating different, but complementary signal transduction pathways.

Because the actual mechanism that leads to differences of final phenotype depend not on single genes but on a global expression pattern, we used cDNA Atlas Arrays to evaluate gene expression profiles after activation of $\mathrm{ER} \alpha$ by different ligands. It has been previously shown that it is possible to group SERMs based on differences and similarities in the pattern of gene expression changes that they produced (Zajchowski et al, 2000). The authors evaluated 24 gene per cell combinations comprising 10 different known oestrogen-responsive genes in eight cell lines representing four cell types. The aim of this study was to examine SERMs on the basis of gene expression profiles using cDNA microarrays in breast cancer cells known to elicit various oestrogenic responses to different compounds.

It is very important to emphasise that in general the differences between gene expression profiles treated with different compounds were very small with correlation coefficients ranging from 0.83 to 0.98 . Our results reflect several limitations of this approach: (i) we treat the same cell line (not a different cell line from different origin) with compounds, so the differences are already very limited; (ii) all these compounds (except ICI) belong to one class of drugs (SERMs) that function through the ER, i.e. have similar mechanism of action; and (iii) very small amount of all human genes are represented on the arrays used. By analogy, when 20 of the tumours were sampled before and after chemotherapy (Perou et $a l, 2000)$ clustering analysis indicated a high degree of similarity within samples derived from the same patient compared with those from different patients. As a consequence, for tumour classification, Sorlie et al (2001) have used the list of genes to include those with significantly greater variation in expression between different tumours than between paired samples from the same tumour.

Our previous classification of SERMs in these two cell lines was based on one single marker of E2-responsiveness in these breast cancer cells: E2 and 4OHT produced oestrogenic effects on the activation of TGF $\alpha$ mRNA in cell expressing wtER $\alpha$ whereas Ral and ICI were anti-oestrogens (Levenson et al, 1998b). With the mutant receptor, Ral became oestrogenic as well (Levenson et al, 1997; Levenson and Jordan, 1998). These observations were extremely important for understanding SERM action once X-ray crystallography of the LBD of ER $\alpha$ with Ral and 4OHT was determined (Brzozowski et al, 1997; Shiau et al, 1998). Resveratrol had the same effects on growth and expression of selected target genes as E2 in both cell lines (Levenson, unpublished data). Both GW and EM, on the other hand, showed similar effect as Ral with D351 but were weakly oestrogenic with mutant D351Y ER (MacGregor Schafer et al, 1999; Bentrem et al, 2001; Levenson et al, 2001). It is hard to predict what impact on classification of SERMs would TGF $\alpha$ have, being just one gene out of $588 \mathrm{cDNA}$ spotted on the arrays, but because the expression of TGF $\alpha$ in all membranes was at background levels, it was not considered at all. This is concern with the technology. Despite this major limitation we proceeded with a global analysis of results.

The most unexpected result was the fact that E2 grouped with $\mathrm{Ral}$ and ICI in cells expressing wtER $\alpha$. With presumed mechanism of action for pure anti-oestrogen ICI, we expected ICI to appear at the most distant branches of dendrogram from E2. The mode of action of ICI recently summarised by Howell et al (2000) is that ICI binds to ER with affinity similar to that of E2, triggers rapid degradation of ER, therefore there is a reduced rate of dimerisation and nuclear localisation of ICI-ER complex with reduced binding of the complex to oestrogen response elements (EREs). There is no precise molecular description of those events, but obviously reduced rate of ER-ICI complex and different conformational changes in the dimmer influence various protein-protein interactions in the transcriptional complex with subsequent transcription of non-ER-mediated genes as well. Although the mode of action of $\mathrm{E} 2$, Ral and ICI is different in terms of direct activation of E2responsive target genes with EREs (Howell et al, 2000), it might be more similar in terms of transcription of other genes. It is known that differences in ERE sequence also impact ER binding 
affinity and transcriptional activity: there is enhanced transcription with 'direct binding' to the consensus ERE and 'tethering' mechanism where ER interacts with another DNA-bound transcription factor (i.e. Sp1, Ap-1) to initiate responsiveness of other target genes (Klinge, 2001; Nilsson et al, 2001). Overall, if we consider that (1) the level of ER protein goes down with E2, Ral and ICI treatments in these cells (Levenson et al, 1998c; Liu et al, 2001) and (2) the Atlas Arrays we used were spotted with PCR-amplified cDNAs for 588 cancer-related genes with a very few E2-responsive genes with putative EREs in their promoter regions, it is fair to say that we are only detecting changes in non-ER-mediated genes. Among E2-responsive genes were TGF $\alpha$, VEGF, BRCA1 on the array. We were surprised to find that ligand-enhanced activation of these genes was only background and we could not obtain significant variations in expression among SERMs-treated cells. Clearly, future ventures to discover signal transduction pathways must employ targeted array technology. Custom build gene arrays specifically designed to address the cell cycle, apoptosis and angiogenesis and replete with oestrogen-responsive genes may be the only way to address mechanistic questions.

\section{REFERENCES}

Bagdade JD, Wolter J, Subbaiah PV, Ryan W (1990) Effects of tamoxifen treatment on plasma lipids and lipoprotein lipid composition. J Clin Endocrinol Metab 70: $1132-1135$

Barrett-Connor E, Cox DA, Anderson PW (1999) The potential of SERMs for reducing the risk of coronary heart disease. Trends Endocrinol Metab 10: $320-325$

Ben-Dor A, Bruhn L, Friedman N, Nachman I, Schummer M, Yakhini Z (2000) Tissue classification with gene expression profiles. J Comput Biol 7: $559-583$

Bentrem DJ, Dardes RC, Liu H, MacGregor-Schafer J, Zapf JW, Jordan VC (2001) Molecular mechanism of action at estrogen receptor alpha of a new clinically relevant antiestrogen (GW7604) related to tamoxifen. Endocrinology 142: $838-846$

Bhat KP, Pezzuto JM (2001) Resveratrol exhibits cytostatic and antiestrogenic properties with human endometrial adenocarcinoma (Ishikawa) cells. Cancer Res 61: 6137-6144

Bittner M, Meltzer P, Chen Y, Jiang Y, Seftor E, Hendrix M, Radmacher M, Simon R, Yakhini Z, Ben-Dor A, Sampas N, Dougherty E, Wang E, Marincola F, Gooden C, Lueders J, Glatfelter A, Pollock P, Carpten J, Gillanders E, Leja D, Dietrich K, Beaudry C, Berens M, Alberts D, Sondak V (2000) Molecular classification of cutaneous malignant melanoma by gene expression profiling. Nature 406: $536-540$

Brzozowski AM, Pike AC, Dauter Z, Hubbard RE, Bonn T, Engstrom O, Ohman L, Greene GL, Gustafsson J-A, Carlquist M (1997) Molecular basis of agonism and antagonism in the oestrogen receptor. Nature 389: $753-$ 758

Catherino WH, Wolf DM, Jordan VC (1995) A naturally occurring estrogen receptor mutation results in increased estrogenicity of a tamoxifen analog. Mol Endocrinol 9: 1053-1063

Chander SK, McCague R, Luqmani Y, Newton C, Dowsett M, Jarman M, Coombes RC (1991) Pyrrolidino-4-iodotamoxifen and 4-iodotamoxifen, new analogues of the antiestrogen tamoxifen for the treatment of breast cancer. Cancer Res 51: 5851-5858

Cohen FJ, Watts S, Shah A, Akers R, Plouffe Jr L (2000) Uterine effects of 3year raloxifene therapy in postmenopausal women younger than age 60 . Obstet Gynecol 95: 104-110

Connor CE, Norris JD, Broadwater G, Willson TM, Gottardis MM, Dewhirst MW, McDonnell DP (2001) Circumventing tamoxifen resistance in breast cancers using antiestrogens that induce unique conformational changes in the estrogen receptor. Cancer Res 61: 2917-2922

Cummings SR, Eckert S, Krueger KA, Grady D, Powles TJ, Cauley JA, Norton L, Nickelsen T, Bjarnason NH, Morrow M, Lippman ME, Black D, Glusman JE, Costa A, Jordan VC (1999) The effect of raloxifene on risk of breast cancer in postmenopausal women: results from the MORE randomized trial. Multiple outcomes of raloxifene evaluation. JAMA 281: $2189-2197$
Finally, we were interested to observe that SERMs up-regulated genes compared to control untreated cells in cells expressing D351 (Figure 1A) whereas in contrast, SERMs down-regulated genes in cells expressing mutant D351Y ER (Figure 2A). The fact that the ER is known to cause a repressive action with oestrogen in transfectants (Levenson and Jordan, 1994) that is entirely opposite from the actions of oestrogen in nature, suggests that SERMs are doing the same with the D351Y ER where responses are more oestrogenlike. Less complex cell systems should be addressed in the future.

\section{ACKNOWLEDGEMENTS}

These studies are supported by Illinois Department of Public Health, Penny Severns Breast and Cervical Cancer Research Fund \#1658002; American Cancer Society, Illinois Division, Inc, \#99-44 awarded to AS Levenson. We are extremely grateful to the Avon Products Foundation for providing the resources to purchase equipment for gene array analysis. We also thank Beth Amundsen for technical support.

Delmas PD, Bjarnason NH, Mitlak BH, Ravoux AC, Shah AS, Huster WJ, Draper M, Christiansen C (1997) Effects of raloxifene on bone mineral density, serum cholesterol concentrations, and uterine endometrium in postmenopausal women. N Engl J Med 337: 1641-1647

Eisen MB, Spellman PT, Brown PO, Botstein D (1998) Cluster analysis and display of genome-wide expression patterns. Proc Natl Acad Sci USA 95: $14863-14868$

Golub TR, Slonim DK, Tamayo P, Huard C, Gaasenbeek M, Mesirov JP, Coller H, Loh ML, Downing JR, Caligiuri MA, Bloomfield CD, Lander ES (1999) Molecular classification of cancer: class discovery and class prediction by gene expression monitoring. Science 286: $531-537$

Gottardis MM, Jordan VC (1987) Antitumor actions of keoxifene and tamoxifen in the N-nitrosomethylurea- induced rat mammary carcinoma model. Cancer Res 47: 4020-4024

Gruvberger S, Ringner M, Chen Y, Panavally S, Saal LH, Borg A, Ferno M, Peterson C, Meltzer PS (2001) Estrogen receptor status in breast cancer is associated with remarkably distinct gene expression patterns. Cancer Res 61: $5979-5984$

Howell A, Osborne CK, Morris C, Wakeling AE (2000) ICI 182,780 (Faslodex): development of a novel, 'pure' antiestrogen. Cancer 89: $817-825$

Jang M, Cai L, Udeani GO, Slowing KV, Thomas CF, Beecher CW, Fong HH, Farnsworth NR, Kinghorn AD, Mehta RG, Moon RC, Pezzuto JM (1997) Cancer chemopreventive activity of resveratrol, a natural product derived from grapes. Science 275: $218-220$

Jiang S-Y, Jordan VC (1992) Growth regulation of estrogen receptor-negative breast cancer cells transfected with complementary DNAs for estrogen receptor. J Natl Cancer Inst 84: 580-591

Jordan VC (2000) Tamoxifen: a personal retrospective. Lancet Oncology 1: $43-49$

Kalocsai P, Shams S (2001) Use of bioinformatics in arrays. Methods Mol Biol 170: $223-236$

Klinge CM (2001) Estrogen receptor interaction with estrogen response elements. Nucleic Acids Res 29: 2905-2919

Labrie F, Labrie C, Belanger A, Simard J, Gauthier S, Luu-The V, Merand Y, Giguere V, Candas B, Luo S, Martel C, Singh SM, Fournier M, Coquet A, Richard V, Charbonneau R, Charpenet G, Tremblay A, Tremblay G, Cusan L, Veilleux R (1999) EM-652 (SCH 57068), a third generation SERM acting as pure antiestrogen in the mammary gland and endometrium. $J$ Steroid Biochem Mol Biol 69: $51-84$

Lee E-S, Schafer JI, Yao K, England G, O’Regan RM, De Los Reyes A, Jordan VC (2000) Cross-resistance of triphenylethylene-type antiestrogens but not ICI 182,780 in tamoxifen-stimulated breast tumors grown in athymic mice. Clin Cancer Res 6: 4893-4899

Levenson AS, Jordan VC (1994) Transfection of human estrogen receptor (ER) cDNA into ER-negative mammalian cell lines. J Steroid Biochem Mol Biol 51: 229-239 
Levenson AS, Catherino WH, Jordan VC (1997) Estrogenic activity is increased for an antiestrogen by a natural mutation of the estrogen receptor. J Steroid Biochem Mol Biol 60: 261-268

Levenson AS, Jordan VC (1998) The key to the antiestrogenic mechanism of raloxifene is amino acid 351 (aspartate) in the estrogen receptor. Cancer Res 58: $1872-1875$

Levenson AS, Jordan VC (1999) Selective oestrogen receptor modulation: molecular pharmacology for the millennium. Eur J Cancer 35: 1974- 1985

Levenson AS, Kwaan HC, Svoboda KM, Weiss IM, Sakurai S, Jordan VC (1998a) Oestradiol regulation of the components of the plasminogen-plasmin system in MDA-MB-231 human breast cancer cells stably expressing the oestrogen receptor. Br J Cancer 78: 88-95

Levenson AS, Svoboda KM, Kwaan HC, Jordan VC (1998b) Agonist activity of antiestrogen-receptor complexes to regulate urokinase plasminogen activator (uPA) and plasminogen activator inhibitor type 1 (PAI-1) endogenous gene expression in breast cancer cells. Cancer Lett 125: 215-220

Levenson AS, Tonetti DA, Jordan VC (1998c) The oestrogen-like effect of 4hydroxytamoxifen on induction of transforming growth factor alpha mRNA in MDA-MB-231 breast cancer cells stably expressing the oestrogen receptor. Br J Cancer 77: 1812-1819

Levenson AS, MacGregor Schafer JI, Bentrem DJ, Pease KM, Jordan VC (2001) Control of the estrogen-like actions of the tamoxifen-estrogen receptor complex by the surface amino acid at position 351. J Steroid Biochem Mol Biol 76: $61-70$

Liu H, Lee E-S, De Los Reyes A, Zapf JW, Jordan VC (2001) Silencing and reactivation of the selective estrogen receptor modulator-estrogen receptor alpha complex. Cancer Res 61: 3632-3639

Love RR, Barden HS, Mazess RB, Epstein S, Chappell RJ (1994) Effect of tamoxifen on lumbar spine bone mineral density in postmenopausal women after 5 years. Arch Intern Med 154: 2585-2588

Luo S, Labrie C, Belanger A, Candas B, Labrie F (1998) Prevention of development of dimethylbenz(a)anthracene (DMBA)-induced mammary tumors in the rat by the new nonsteroidal antiestrogen EM-800 (SCH57050). Breast Cancer Res Treat 49: 1-11

MacGregor Schafer JI, Liu H, Tonetti DA, Jordan VC (1999) The interaction of raloxifene and the active metabolite of the antiestrogen EM-800 (SC 5705) with the human estrogen receptor. Cancer Res 59: 4308-4313

Martel C, Picard S, Richard V, Belanger A, Labrie C, Labrie F (2000) Prevention of bone loss by EM- 800 and raloxifene in the ovariectomized rat. $J$ Steroid Biochem Mol Biol 74: 45-56

Mizutani K, Ikeda K, Kawai Y, Yamori Y (2000) Resveratrol attenuates ovariectomy-induced hypertension and bone loss in stroke-prone spontaneously hypertensive rats. J Nutr Sci Vitaminol (Tokyo) 46: 78-83

Morrow M, Jordan VC (2000) Tamoxifen to prevent breast cancer. Adv Surg 34: $287-299$

Nilsson S, Makela S, Treuter E, Tujague M, Thomsen J, Andersson G, Enmark E, Pettersson K, Warner M, Gustafsson J-A (2001) Mechanisms of estrogen action. Physiol Rev 81: $1535-1565$

Nuttall ME, Bradbeer JN, Stroup GB, Nadeau DP, Hoffman SJ, Zhao H, Rehm S, Gowen M (1998) Idoxifene: a novel selective estrogen receptor modulator prevents bone loss and lowers cholesterol levels in ovariectomized rats and decreases uterine weight in intact rats. Endocrinology 139: $5224-5234$

Perou CM, Sorlie T, Eisen MB, van de Rijn M, Jeffrey SS, Rees CA, Pollack JR, Ross DT, Johnsen H, Akslen LA, Fluge O, Pergamenschikov A, Williams C, Zhu SX, Lonning PE, Borresen-Dale AL, Brown PO, Botstein D (2000) Molecular portraits of human breast tumours. Nature 406: 747-752
Ross DT, Scherf U, Eisen MB, Perou CM, Rees C, Spellman P, Iyer V, Jeffrey SS, Van de Rijn M, Waltham M, Pergamenschikov A, Lee JC, Lashkari D, Shalon D, Myers TG, Weinstein JN, Botstein D, Brown PO (2000) Systematic variation in gene expression patterns in human cancer cell lines. Nat Genet 24: 227-235

Ryan WG, Wolter J, Bagdade JD (1991) Apparent beneficial effects of tamoxifen on bone mineral content in patients with breast cancer: preliminary study. Osteoporos Int 2: 39-41

Shiau AK, Barstad D, Loria PM, Cheng L, Kushner PJ, Agard DA, Greene GL (1998) The structural basis of estrogen receptor/coactivator recognition and the antagonism of this interaction by tamoxifen. Cell 95: 927-937

Sorlie T, Perou CM, Tibshirani R, Aas T, Geisler S, Johnsen H, Hastie T, Eisen MB, van de Rijn M, Jeffrey SS, Thorsen T, Quist H, Matese JC, Brown PO, Botstein D, Eystein Lonning P, Borresen-Dale AL (2001) Gene expression patterns of breast carcinomas distinguish tumor subclasses with clinical implications. Proc Natl Acad Sci USA 98: 10869-10874

Tamayo P, Slonim D, Mesirov J, Zhu Q, Kitareewan S, Dmitrovsky E, Lander ES, Golub TR (1999) Interpreting patterns of gene expression with selforganizing maps: methods and application to hematopoietic differentiation. Proc Natl Acad Sci USA 96: 2907-2912

Tonetti DA, Jordan VC (1995) Possible mechanisms in the emergence of tamoxifen-resistant breast cancer. Anticancer Drugs 6: 498-507

Toronen P, Kolehmainen M, Wong G, Castren E (1999) Analysis of gene expression data using self-organizing maps. FEBS Lett 451: 142-146

Wakeling AE, Bowler J (1987) Steroidal pure antioestrogens. J Endocrinol 112: R7-R10

Wakeling AE, Dukes M, Bowler J (1991) A potent specific pure antiestrogen with clinical potential. Cancer Res 51: 3867-3873

Welsh JB, Sapinoso LM, Su AI, Kern SG, Wang-Rodriguez J, Moskaluk CA, Frierson Jr HF, Hampton GM (2001) Analysis of gene expression identifies candidate markers and pharmacological targets in prostate cancer. Cancer Res 61: 5974-5978

Wijayaratne AL, Nagel SC, Paige LA, Christensen DJ, Norris JD, Fowlkes DM, McDonnell DP (1999) Comparative analyses of mechanistic differences among antiestrogens. Endocrinology 140: $5828-5840$

Willson TM, Henke BR, Momtahen TM, Charifson PS, Batchelor KW, Lubahn DB, Moore LB, Oliver BB, Sauls HR, Triantafillou JA, Wolfe SG, Baer PG (1994) 3-[4-(1,2-Diphenylbut-1-enyl)phenyl]acrylic acid: a non-steroidal estrogen with functional selectivity for bone over uterus in rats. J Med Chem 37: 1550 - 1552

Willson TM, Norris JD, Wagner BL, Asplin I, Baer P, Brown HR, Jones SA, Henke B, Sauls H, Wolfe S, Morris DC, McDonnell DP (1997) Dissection of the molecular mechanism of action of GW5638, a novel estrogen receptor ligand, provides insights into the role of estrogen receptor in bone. Endocrinology 138: $3901-3911$

Wu JM, Wang ZR, Hsieh TC, Bruder JL, Zou JG, Huang YZ (2001) Mechanism of cardioprotection by resveratrol, a phenolic antioxidant present in red wine (Review). Int J Mol Med 8: 3-17

Zajchowski DA, Kauser K, Zhu D, Webster L, Aberle S, White IIIFA, Liu HL, Humm R, MacRobbie J, Ponte P, Hegele-Hartung C, Knauthe R, Fritzemeier KH, Vergona R, Rubanyi GM (2000) Identification of selective estrogen receptor modulators by their gene expression fingerprints. J Biol Chem 275: $15885-15894$ 